\title{
Participation Appraisal of Women Farmers in Dairy Husbandry Practices in Indo-Pak Border Area of Punjab (India)
}

\author{
Sumanpreet Kaur ${ }^{1 *}$, Jaswinder Singh ${ }^{1} *$, H.K. Verma ${ }^{2}$, \\ Shakti Kant Dash ${ }^{3}$ and S.K. Kansal ${ }^{1}$
}

${ }^{1}$ Department of Veterinary and Animal Husbandry Extension Education, ${ }^{2}$ Directorate of Extension Education, ${ }^{3}$ Department of Animal Genetics and Breeding, Guru Angad Dev

Veterinary and Animal Sciences University, Ludhiana, Punjab, India

*Corresponding author

\begin{abstract}
A B S T R A C T
India being the agriculture based country; livestock sector becomes the backbone of the nation's development in terms of economy and various other sectors as well. Livestock production serves as the main source of employment, income and food for over seventy percent of Indian population and women play the role of the hidden working force behind the establishment of livestock sector. A study was conducted on 160 women dairy farmers of 4 border districts namely Gurdaspur, Amritsar, Taran-Taran and Ferozepur of Punjab to ascertain their participation level in various practices related to dairy farming. A pretested structured questionnaire comprising questions on various livestock management practices was filled during the personal interview with women farmers. Data so collected was analyzed descriptively to draw inference. Majority women (70\%) had medium level of participation and factors like age, land holding, farm milk production, herd size and number of animal labourer were found to be inversely correlated with the participation score $(\mathrm{p}<0.05)$. Study concluded that women are diversely involved in various dairy farming practices and their role is required to be scientifically strengthened through policies and extension activities.
\end{abstract}

\section{Introduction}

The prosperity and growth of a nation depends on the status and development of its women as they not only constitute nearly half of the population, but also positively influence the growth of remaining half of the population. India being the leading country in milk production contributed annual milk production of 155.5 million tons during 2015-16
(Department of Animal husbandry, Dairying \& Fisheries, Ministry of Agriculture, Government of India), accounting for about $18.5 \%$ of world production. This signifies that dairying is a significant means of livelihood to millions of rural farmers. The rural women play a significant role in animal husbandry and are involved in practices like feeding, breeding, management and health care. Women spend most of their time in care and 
management of the dairy animals. Being key players in flourishment of the dairy industry, women are a helping hand in dairy enterprise. Growing demand for milk and milk products in recent years strengthens dairy farming as a lucrative enterprise for women (Mohapatra $e t$ al., 2012). They constitute 71 per cent of the labor force in livestock farming. In India, about 75 million women are engaged as against 15 million men in dairying (Thakur and Chander, 2006). A study conducted by Kacker (2006) also revealed that majority (85 $\%)$ of persons engaged in dairy production is women. Majority $(68.75 \%)$ of Border area women in Punjab has medium knowledge level on various recommended dairy farming practices (Kaur et al., 2017). India on its North-western side, shares its border with Pakistan. Punjab is one of the Border States in India sharing approximately 553 kilometers of international border with Pakistan. The border area of Punjab, includes Ferozepur, TaranTaran, Amritsar and Gurdaspur districts, is the most disadvantaged one due to its strategic location (Fig. 1). Numerous innovations, facilities and government schemes are not reaching to the farmers especially women dairy farmers of the border area. Considering the above, present study was planned to study the participation level of women of border area on various aspects of dairy farming.

\section{Materials and Methods}

This study was conducted in four districts namely Gurdaspur, Amritsar, Taran taran and Ferozepur of border area of Punjab (Fig. 1). Families owning minimum three animals were selected for study. A sample of forty was randomly selected from 4 villages from each of the four selected districts. Thus the total sample comprised of 160 women farmers. The data were collected personally with the help of structured interview schedule. Various animal husbandry practices like milking, feeding, watering were enlisted and the maximum score was given to the activities which were carried out by women themselves to ascertain their participation in the same. The total score for each individual was calculated and that score was denoted as participation score and categorization of the same was done on the basis of low ( $<$ mean - standard deviation), medium (mean - standard deviation to mean + standard deviation) and high (> mean + standard deviation). Data collected were statistically analyzed with the help of SPSS 20 software.

\section{Results and Discussion}

\section{Socio-economic profile of women dairy farmers}

The socio-economic profile of women highlights that majority $(66.25 \%)$ of women were from middle age group and $43.13 \%$ had education up to high school (Table 1). The family size of most (65.62\%) of the respondents was small. The findings are in line with those of Kaur (2015) who found that majority $(66.0 \%)$ of respondents was from lower middle age group and majority was having education up to secondary $(28.0 \%)$. Though not even a single women own a chunk of land because in Punjab traditionally land is owned by male member of the family generation by generation. Majority respondents' (69.37\%) family land holding ranged between less than one hectare and four hectare (Table 1). Most (49.37\%) of the respondents had small (> 5 animals) herd size, around $38.75 \%$ respondents household were producing less than fifteen liters of milk/day and majority $(83.13 \%)$ of dairy farm women were of general category. The findings are in line with those of Ahirwar et al., (2016). In contrast, Nataraju (2012) concluded that over half $(51.66 \%)$ of the respondents fall under medium level of livestock possession followed by 26.66 and 21.66 per cent of them under low and high category of livestock possession 
respectively. This may be explained with the fact that in the non-border area the economic status of the farmers is comparatively sound as compared to those of the border area. The findings were found to be in line with those of Arora et al., (2006) and Mande and Thombre (2009).

Participation of women in various jobs related to livestock management

Activities like cleaning of the animals and shed $(58.13 \%)$, milking $(75.63 \%)$, taking animals in and out of the shed (44.37\%), handling of milk (86.25), cleaning of milk utensils $(81.88 \%)$, disposal of dung $(53.75 \%)$ were mainly performed by dairy farm women themselves. Feeding and watering of the animals was comparatively less women dependent activity as male members of the family or animal labourer predominantly did this. One fourth to little over one third women were involved in concentrate feeding and disposal of surplus milk respectively. Most $(40.63 \%)$ of the women had hired workers for taking the animals for grazing, to fields or to the ponds. Only $10 \%$ and $11.88 \%$ of dairy farm women were bringing the fodder for their animals and chaffing the fodder by themselves, respectively (Fig. 2). Around 60\% respondents' family members were taking the sick animals to the hospital and care the animal around calving, respectively.

About one-third (31.25\%) of dairy farm women make the cow dung cakes by themselves (Table 2). Previous study revealed that women were fully involved and responsible for the jobs related to care and management of their domestic animals (Agarwal, 1987), in milking, caring of new born animals, cleaning of animal sheds, feeding and disposal of dung (Rathod et al., 2011), watering the animals, storage of feed and fodder, feeding the animals and mixing green fodder with roughage (Kaur, 2015)
Overall participation level of dairy farm women in various activities related to animal husbandry

The categorization of dairy farm women was done according to the participation score as low (<Mean-standard deviation), medium (mean \pm standard deviation) and high participation (>mean + standard deviation). Low score is less than 64.58 participation score, medium as between 64.58 to 119.14 and high as greater than 119.14. The total score calculated was 150. Maximum respondents i.e. $70 \%$ had medium participation, $16.87 \%$ had low and only $13.13 \%$ had high participation score (Table 3).

Effect of various independent variables on participation score:

Age, education and herd size had a significant effect $(\mathrm{P}<0.05)$ on the participation score of dairy farm women (Table 4). District did not have any significant effect on the overall participation score of the dairy farm women. Rathod et al., (2011) also found the significant effect of independent variable viz. age, land holding, livestock possession and social participation on the extents of participation of women in dairy farming operations.

Among non-border areas, eight variables namely, education, income, dairy experience, livestock possession, mass media participation, social participation, extension participation and risk orientation had positive and significant relationship at 0.05 level of probability, whereas decision making ability and economic motivation had positive and significant relationship at 0.01 level of probability with their participation of women in dairy Nataraja (2012). These findings were also in agreement with findings of Chauhan et al., (2004), Arora et al., (2006) and Mande and Thombre (2009). 
Correlation of various variables with the Participation Score

The factors like age, land holding, farm milk production, herd size and no. of workers were found to be inversely correlated with the participation score (Table 5). The results were in line with the findings of Rathod et al., (2011), who found that out of the independent variables put to the correlational analysis, only four variables namely, age, land holding, livestock possession and social participation were highly significant while the remaining variables failed to attain the statistical level of significance. The variables age, education, annual income, land holding and social participation were negatively correlated while factors like family type, marital status and livestock possession were positively correlated.

Table.1 Socio- economic profile of dairy farm women

\begin{tabular}{|c|c|c|c|c|}
\hline S.No. & Particulars & Response & Frequency & \%age \\
\hline \multirow[t]{3}{*}{1} & \multirow[t]{3}{*}{ Age } & $\begin{array}{l}\text { Young: Less than (Mean- } \\
\text { S.D.) }\end{array}$ & 27 & 16.87 \\
\hline & & $\begin{array}{l}\text { Middle: (Mean- S.D.) to } \\
\text { (Mean + S.D) }\end{array}$ & 106 & 66.25 \\
\hline & & $\begin{array}{l}\text { Old: More than (Mean + } \\
\text { S.D) }\end{array}$ & 27 & 16.87 \\
\hline \multirow[t]{6}{*}{2} & \multirow[t]{6}{*}{ Education } & Illiterate & 54 & 33.75 \\
\hline & & Up to Primary school & 6 & 3.75 \\
\hline & & Up to Middle school & 5 & 3.13 \\
\hline & & Up to High School & 69 & 43.13 \\
\hline & & Up to Graduate & 22 & 13.70 \\
\hline & & Graduate and above & 4 & 2.50 \\
\hline \multirow[t]{3}{*}{3} & \multirow[t]{3}{*}{ Family size } & Up to 4 members & 105 & 65.62 \\
\hline & & 5 to 9 members & 52 & 32.50 \\
\hline & & More than 9 members & 3 & 1.87 \\
\hline \multirow[t]{6}{*}{4} & \multirow[t]{6}{*}{ Land holding } & Landless & 15 & 9.37 \\
\hline & & $<1$ Hectare (Marginal) & 16 & 10.00 \\
\hline & & 1 - 2 Hectare (Small) & 27 & 16.87 \\
\hline & & 2-4 Hectare (Semi-medium) & 37 & 23.13 \\
\hline & & 4-10 Hectare (Medium) & 31 & 19.37 \\
\hline & & $>10$ Hectare (Large) & 34 & 21.25 \\
\hline \multirow[t]{3}{*}{5} & \multirow[t]{3}{*}{ Herd Size } & Small: up to 5 animals & 79 & 49.37 \\
\hline & & Medium: 6 to 9 animals & 41 & 25.63 \\
\hline & & Large: 10 or above animals & 40 & 25.00 \\
\hline \multirow[t]{3}{*}{6} & \multirow{3}{*}{$\begin{array}{ll}\text { Farm } & \text { Milk } \\
\text { Production } & \end{array}$} & Low & 62 & 38.75 \\
\hline & & Medium & 60 & 37.50 \\
\hline & & High & 38 & 23.75 \\
\hline \multirow[t]{3}{*}{7} & \multirow[t]{3}{*}{ Category } & General & 133 & 83.13 \\
\hline & & S.C. & 17 & 10.63 \\
\hline & & Others & 10 & 6.25 \\
\hline
\end{tabular}


Table.2 Participation of dairy farm women in various jobs related to livestock management

\begin{tabular}{|c|c|c|c|c|}
\hline Sr. No & Jobs related to livestock management & Who does the job? & Frequency & \%age \\
\hline \multirow[t]{3}{*}{1.} & \multirow[t]{3}{*}{ Cleaning of the animals and shed } & Self & 93 & 58.13 \\
\hline & & Males of the family/children & 6 & 3.75 \\
\hline & & Animal worker & 61 & 38.12 \\
\hline \multirow[t]{3}{*}{2.} & \multirow[t]{3}{*}{ Milking } & Self & 121 & 75.63 \\
\hline & & Males of the family/children & 8 & 5.00 \\
\hline & & Animal worker & 31 & 19.37 \\
\hline \multirow[t]{3}{*}{3.} & \multirow[t]{3}{*}{ Taking animals in and out of the shed } & Self & 71 & 44.37 \\
\hline & & Males of the family/children & 32 & 20.00 \\
\hline & & Animal worker & 57 & 35.63 \\
\hline \multirow[t]{3}{*}{4.} & \multirow[t]{3}{*}{ Handling of milk } & Self & 138 & 86.25 \\
\hline & & Males of the family/children & 13 & 8.13 \\
\hline & & Animal worker & 9 & 5.63 \\
\hline \multirow[t]{3}{*}{5.} & \multirow[t]{3}{*}{ Cleaning of milk utensils } & Self & 131 & 81.88 \\
\hline & & Males of the family/children & 2 & 1.25 \\
\hline & & Animal worker & 27 & 16.88 \\
\hline \multirow[t]{3}{*}{6.} & \multirow[t]{3}{*}{ Dung disposal } & Self & 67 & 41.88 \\
\hline & & Males of the family/children & 7 & 4.38 \\
\hline & & Animal worker & 86 & 53.75 \\
\hline \multirow[t]{3}{*}{7.} & \multirow[t]{3}{*}{ Feeding and watering of the animals } & Self & 44 & 27.50 \\
\hline & & Males of the family/children & 50 & 31.25 \\
\hline & & Animal worker & 66 & 41.25 \\
\hline \multirow[t]{3}{*}{8.} & \multirow[t]{3}{*}{ Concentrate feeding } & Self & 40 & 25.00 \\
\hline & & Males of the family/children & 49 & 30.63 \\
\hline & & Animal worker & 71 & 44.37 \\
\hline \multirow[t]{3}{*}{9.} & \multirow[t]{3}{*}{ Disposal of surplus milk } & Self & 56 & 35.00 \\
\hline & & Males of the family/children & 68 & 42.50 \\
\hline & & Animal worker & 36 & 22.50 \\
\hline \multirow[t]{4}{*}{10.} & \multirow{4}{*}{$\begin{array}{l}\text { Taking animals for grazing/fields/ } \\
\text { pond }\end{array}$} & None & 28 & 17.50 \\
\hline & & Self & 23 & 14.37 \\
\hline & & Males of the family/children & 44 & 27.50 \\
\hline & & Animal worker & 65 & 40.63 \\
\hline \multirow[t]{3}{*}{11.} & \multirow[t]{3}{*}{ Bringing fodder for animals } & Self & 16 & 10.00 \\
\hline & & Males of the family/children & 57 & 35.63 \\
\hline & & Animal worker & 87 & 54.37 \\
\hline 12. & Chaffing of the fodder & Self & 19 & 11.87 \\
\hline & & Males of the family/children & 56 & 35.00 \\
\hline & & Animal worker & 85 & 53.13 \\
\hline 13. & Taking sick animal to the hospital & Call the doctor at home & 6 & 3.75 \\
\hline & & Self & 22 & 13.75 \\
\hline & & Males of the family/children & 95 & 59.38 \\
\hline & & Animal worker & 37 & 23.13 \\
\hline 14. & Caring the animal around calving & Self & 34 & 21.25 \\
\hline & & Males of the family/children & 96 & 60.00 \\
\hline & & Animal worker & 30 & 18.75 \\
\hline 15. & Making Cow dung cakes & None & 32 & 20.00 \\
\hline & & Self & 50 & 31.25 \\
\hline & & Females of the family/girl children & 31 & 19.37 \\
\hline & & Animal worker & 47 & 29.37 \\
\hline
\end{tabular}


Table.3 Overall participation score of dairy farm women

\begin{tabular}{|l|l|l|l|}
\hline Sr. No & Category & Frequency & \%age \\
\hline $\mathbf{1}$ & Low $(<64.58)$ & 27 & 16.87 \\
\hline $\mathbf{2}$ & Medium(64.58 to 119.14$)$ & 112 & 70.00 \\
\hline $\mathbf{3}$ & High $(>119.14)$ & 21 & 13.13 \\
\hline
\end{tabular}

Table.4 Effect of various independent variables on participation score

\begin{tabular}{|l|l|l|}
\hline Categories & Sub-Categories & Mean \pm S.E \\
\hline \multirow{5}{*}{ Age } & Young & $70.00 \pm 3.08^{\mathrm{b}}$ \\
\hline \multirow{2}{*}{ District } & Middle & $58.90 \pm 1.60^{\mathrm{a}}$ \\
\hline & Old & $60.59 \pm 3.18^{\mathrm{a}}$ \\
\hline \multirow{5}{*}{ Education } & TaranTaran & $63.51 \pm 2.67$ \\
\hline & Amritsar & $56.38 \pm 2.68$ \\
\hline & Gurdaspur & $60.56 \pm 2.59$ \\
\hline & Ferozepur & $63.83 \pm 2.82$ \\
\hline \multirow{5}{*}{ Herd Size } & Low & $62.57 \pm 2.28^{\mathrm{b}}$ \\
\hline & Medium & $64.14 \pm 1.99^{\mathrm{b}}$ \\
\hline & High & $48.67 \pm 3.01^{\mathrm{a}}$ \\
\hline & Small & $69.15 \pm 1.95^{\mathrm{c}}$ \\
\hline & Medium & $58.97 \pm 2.52^{\mathrm{b}}$ \\
\hline & Large & $47.23 \pm 2.65^{\mathrm{a}}$ \\
\hline
\end{tabular}

${ }^{\mathrm{a}, \mathrm{b}}$ and ${ }^{\mathrm{c}} \ldots \ldots$..... significant at $\mathrm{p}<0.05$

Table.5 Correlation of various variables with participation score

\begin{tabular}{|l|l|l|l|}
\hline Sr. No. & Variable & r value & P value \\
\hline $\mathbf{1}$ & Age & $-0.242^{* *}$ & 0.002 \\
\hline $\mathbf{2}$ & Education & -0.105 & 0.184 \\
\hline $\mathbf{3}$ & Family size & -0.010 & 0.904 \\
\hline $\mathbf{4}$ & Land holding & $-0.486^{* *}$ & 0.000 \\
\hline $\mathbf{5}$ & Farm milk production & $-0.452^{* *}$ & 0.000 \\
\hline $\mathbf{6}$ & Herd size & $-0.494^{* *}$ & 0.000 \\
\hline $\mathbf{7}$ & No. of workers & $-0.625^{* *}$ & 0.000 \\
\hline
\end{tabular}

. Significant at $\mathrm{P}<0.01$ 
Fig.1 International border and sample area

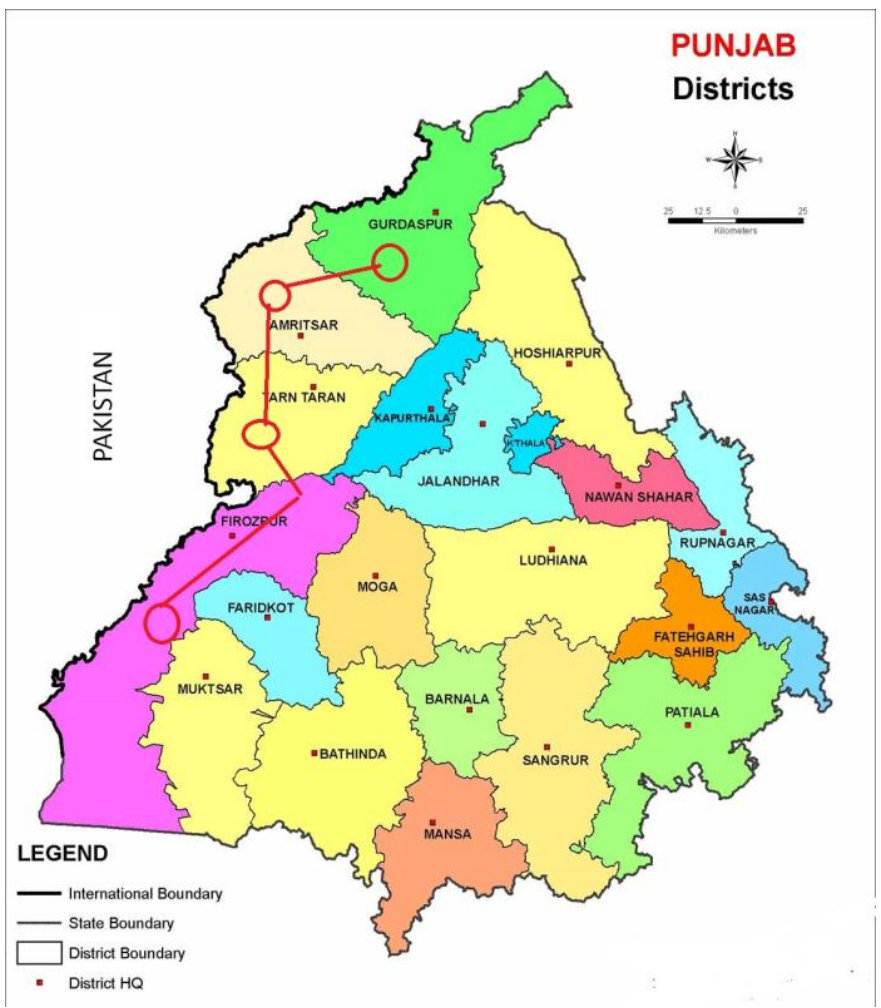

Fig.2 Animal Husbandry activities carried out by women

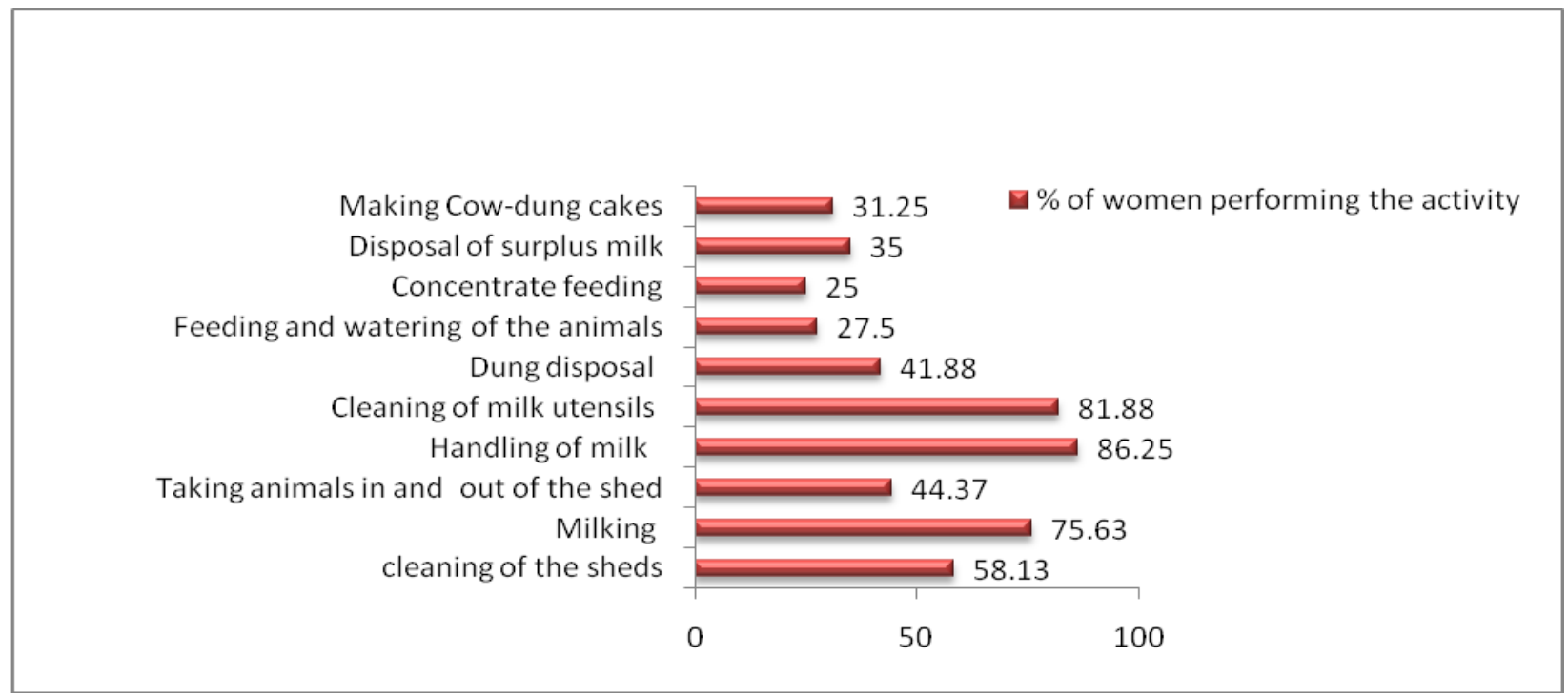

From the above study we can conclude that a majority $(70 \%)$ of border area women were having medium participation in various activities related to animal husbandry followed by $16.87 \%$ having low and $13.13 \%$ having high participation level. Education, age and herd size had significant effect on the participation score of dairy farm women. So, in order to avail maximum benefit from the dairy industry women must be involved in the 
various extension activities and special women focused training programmes as well as camps must be organized.

\section{References}

Agarwal, H. A study on contribution of farm women in animal husbandry enterprise'.M.V.Sc. Thesis, Indian Veterinary Research Institute, Izatnagar, India.1987.

Ahirwar, M. K., Singh, H. S., Patel, R. K., and Mondal, M. K. Socio-Personal and Economic Profile of Peri-Urban and rural dairy farmers in Rewa district of Madhya Pradesh. International Journal of Agriculture Sciences. 2016; 8(63): 3548-51.

Arora, A. S., Avadhesh Kumar, Bardhan, D. And Dabas, Y. P. S., Socio-Economic and communication variables associated with level of knowledge and degree of adoption of improved dairy husbandry practiced in Uttaranchal. Indian J. Dairy Sci. 2006; 59 (5):337-343.

Chauhan, D. S., Kamble, V. J., Padghan, P. V., Sawant, R. C. And Kamble, R. R.,Impact of farmers status on milk production in tribal area of Kinwat Thasil (Marathwada Region). Indian J. Animal Res. 2004; 38 (2): 137-140.

Department of Animal Husbandry, Dairying $\&$ Fisheries, Ministry of Agriculture, Government of India www.nddb.org/ information/stats/milkprodindia.

Kacker, L. SHGs and Women, Yojana, March. 2006; 50:73-74
Kaur, K. Participation of rural women in dairy activities. Journal of Krishi Vigyan. 2015; 4: 72-75.

Kaur, S., Verma, H.K., Jaswinder Singh, Shakti Kant Dash and S.K. Kansal. Knowledge Level of Women Dairy Farmers about Various Farming Practices in Border Area of Punjab. Journal of Animal Research, 2017; 7: 1051-1059.

Mande, J. V. And Thombre, B. M. Adoption of cattle rearing practices by owners in Latur district. Dairying Foods and Home Sci. 2009; 28 (3/4): 176- 180.

Mohapatra, A. S., Behera, R. and Sahu, U. P. Constraints faced by tribal entrepreneurs in dairy farming enterprise. International Journal of Physiology and Social Science, 2012; 2: 171-84.

Nataraju, B. Study on Participation of Women in Dairy Farming in Chickmagalur District (Doctoral dissertation, University of Agricultural Sciences GKVK, Bangalore) 2012.

Rathod, P. K., Nikam, T. R., Landge, S., Vajreshwari, S. and Hatey. Participation of Rural Women in Dairy Farming in Karnataka. Indian Research Journal of Extension Education 2011; 11: 31-36.

Thakur, D. and Chandar, M. Gender based differential access to information among Livestock owners and its impact on house hold milk production in Kangra district of Himachal Pradesh. Indian Journal of Dairy Science, 2006; 59: 401-404.

\section{How to cite this article:}

Sumanpreet Kaur, Jaswinder Singh, H.K. Verma, Shakti Kant Dash and Kansal, S.K. 2019. Participation Appraisal of Women Farmers in Dairy Husbandry Practices in Indo-Pak Border Area of Punjab (India). Int.J.Curr.Microbiol.App.Sci. 8(05): 2298-2305. doi: https://doi.org/10.20546/ijcmas.2019.805.271 